\title{
Współbycie, współodpowiedzialność i współzależność jako kategorie ważne dla pedagogiki społecznej skierowanej ku budowaniu wspólnot lokalnych
}

\section{KEYWORDS}

Coexistence, shared responsibility, interdependence

\begin{abstract}
Naumiuk Agnieszka, Współbycie, współodpowiedzialność i współzależność jako kategorie ważne dla pedagogiki społecznej skierowanej ku budowaniu wspólnot lokalnych [Coexistence, co-responsibility and interdependence as categories important to social pedagogy directed towards building local communities]. Kultura Społeczeństwo - Edukacja nr 1(17) 2020, Poznań 2020, pp. 53-62, Adam Mickiewicz University Press. ISSN 23000422. DOI 10.14746/kse.2020.17.3.1
\end{abstract}

The article analyzes three categories: co-existence, coresponsibility and interdependence in the context of contemporary discussions about the role of social pedagogy in building local communities. New possible approaches arise while using these concepts for addressing contemporary conditions of the communities which result in new tasks of education. There are analysed also the consequences of the transformation from the previous rather static (territorial) view of local communities, that had the aim to root people in existing social structures, towards more dynamic, open and diverse spaces. They are not considered only as physical places anymore but as new local relations that are being developed, based on not stable, however increasingly popular forms of sharing experiences. For these changes the studied concepts match the new realities and in consequence demand pedagogical considerations.

\footnotetext{
* ORCID https://orcid.org//0000-0001-5390-4263.
} 


\section{Wprowadzenie}

Budowanie wspólnot lokalnych jest procesem, którego ramy wydają się nieostre, czego konsekwencją jest trudność w ustalaniu konkretnych celów oraz kryteriów skuteczności owego działania. Koncepcja ta jednak staje się w ostatnich latach jednym z kluczowych zagadnień Unii Europejskiej (Banaszak, 2014, por. także Polityka Spójności UE, 2014), gdyż w nawet najsprawniej zarządzanych systemach wyłania się potrzeba poczucia bliskości, bezpieczeństwa, życia w atmosferze życzliwości i zaufania, mimo iż nadal wydaje się to raczej odległym marzeniem (Bauman, 2008: 5-11).

Polska, w której rodzina i ojczyzna stanowiły od wieków główne punkty odniesienia $\mathrm{w}$ wartościowaniu relacji międzyludzkich, miała wiele obiektywnych geopolitycznych trudności w kształtowaniu zintegrowanych przestrzeni lokalnych. Stąd też pytanie pedagogiki społecznej o sens ich tworzenia wydaje się, zwłaszcza w naszym kraju, zasadne (Radziewicz-Winnicki, 2013; Skrzypczak, 2016). Dyskusje o roli wspólnego życia w skali mezospołecznej nieustająco jednak powracają i domagają się odpowiedzi w postaci określonych współczesnych rozwiązań, ale także pojawiły się w rozważaniach o roli pedagogów w odniesieniu do fundamentalnych wartości (Theiss, 2018: 118; Pilch, 2018, 39: 50-52). Po trzydziestu latach budowania nowych warunków życia społecznego Polska demokracja wydaje się już na tyle dojrzała, że istnieje szansa, iż potrafi obiektywniej ocenić, na ile prospołeczne działania funkcjonują jedynie w wyniku sterowania zewnętrznego i jako efekt przymusu, a na ile wynikają $z$ wewnętrznych potrzeb relacji z innymi i poprzez uczestnictwo doświadczania siebie jako istot społecznych.

Wiele cennych inicjatyw lokalnych i sąsiedzkich niemal z dnia na dzień zostało uruchomionych zarówno w formule niezależnych działań oddolnych, jak i w postaci projektów różnorodnych instytucji (Szczurek-Boruta i in., 2014; Segiet i in., 2017, zob. także między innymi projekt Działaj lokalnie Akademii Rozwoju Filantropii czy projekty animatorów $\mathrm{CAL}^{1}$ ). Zmierzają one do wzajemnego poznawania się ludzi, tworzenia więzi, rozumienia siebie nie tylko w indywidualnym, ale i zbiorowym kontekście. Nie jest to jednak łatwe zadanie w obliczu zarówno określonych procesów globalnej nowomowy, zwłaszcza terminów i formuł zawłaszczających oraz upraszczających pojęcie wspólnoty, jak i wobec tendencji, by wspólnotowe działania interpretować w duchu nacjonalizmów, wykluczania i w swej istocie walki ze wspólnotowymi ideałami demokracji (Mendel, Naumiuk, Skrzypczak, 2018).

${ }^{1}$ Zob. http://www.cal.org.pl/english-version/ i http://dzialajlokalnie.pl/about-act-locally-program. 
Zadaniem pedagogów jest obserwowanie warunków rozwoju i zmiany tradycji lokalnych w podtrzymywaniu więzi społeczno-kulturowych oraz namysł nad tym, które z nich, w jaki sposób i na jakich zasadach, można i warto wpisywać w celowe założenia inkluzji: które są tylko działaniami pozorowanymi, a które w istocie rzeczy przeczą ideałom stanowiącym fundamenty zintegrowanej wspólnoty (por. Dryżałowska i in., 2019, Segiet i in., 2017).

\section{Zmiany w postrzeganiu i interpretowaniu dynamizmów społeczności lokalnej}

Jako pedagodzy społeczni przyzwyczailiśmy się używać określonych terminów, które wpisane są w kanon naszej dyscypliny, bez których nie wyobrażamy sobie budowania naszej profesjonalnej tożsamości badawczej, realizacji określonych idei w praktyce czy dyskusji o roli wychowania w środowisku. W naszym pedagogicznym dorobku ważne jest, jak traktujemy i interpretujemy określone pojęcia, gdyż stanowią one dla nas ramę koncepcyjną przyjmowanych sposobów oglądu rzeczywistości. Takim interesującym określeniem, będącym jednocześnie wyzwaniem interpretacyjnym, jest kategoria „pedagogiki współbycia”. Poszerzając rozumienie tego terminu, funkcjonującego między innymi w ramach innowacyjnej edukacji szkolnej (Dymara, 2014), o obszar działań środowiskowych, można wskazać jego walory i przydatność do interpretacji działania w przestrzeni życia lokalnego w ramach pedagogiki społecznej.

Wydaje się, iż pewne stałe, tradycyjne formuły przez nas używane nadal mogą być niejasne, niekompletne. Dla jednych badaczy i praktyków jest to wyzwanie do dookreślania i dodefiniowywania, dla innych okazja do dostrzegania elementów nowej jakości, przekraczania granic standardowego myślenia o lokalności. Tak się dzieje, między innymi, także z wieloletnimi dylematami rozumienia, definiowania i używania terminu „społeczność lokalna”. Myśląc w kategoriach analiz językowych, gdzie mamy podmiot: społeczność i jego przymiot: lokalna, kierunkujemy nasze myślenie ku pewnemu określonemu bytowi społecznemu o ograniczonym obszarze w przestrzeni fizycznej. Podejście socjologiczne bywa dla pedagogiki w pewien sposób ograniczeniem, a używanie koncepcji zachodnioeuropejskich niewiele pomaga w kontekście specyfiki polskiej. Staramy się temu bytowi nadać zakres, cechy, sens społeczny, ustalić typy analiz, zakorzenić w kulturze, wprowadzić do tradycji sił modelujących procesy wychowawcze w Polsce (Smolińska-Theiss, 1991; Theiss, Skrzypczak, 2006). Badamy w związku z tym między innymi właściwości naszej świadomości zbiorowej wynikającej z przyjętych (przyjmowa- 
nych) przez tę zbiorowość zasad, tak, aby jak najlepiej dopasować do niej nasze pedagogiczne zamiary (Winiarski, 2006; 2017).

Dylematy narastają, gdy mamy świadomość tego, iż, jak wskazuje Tadeusz Pilch, pojęcie „społeczność lokalna” nie jest tożsame z pojęciem „środowisko lokalne", choć stosowane one bywają zamiennie i cechują je podobne, choć nieidentyczne desygnaty (Pilch, 2006: 413). Pedagodzy społeczni w swoich opracowaniach o pracy „ze społecznością lokalną” lub „dla społeczności lokalnej” używają tego określenia, między innymi, jako pewnej przestrzeni działania rozwoju jednostek i grup (Bąbska, Rymsza, 2014).

Zdając sobie oczywiście sprawę z tego, że myślimy i mówimy skrótami, traktujemy z czasem coraz bardziej stereotypowo i enigmatycznie ów „byt zbiorowy”. W praktyce rodzą się pytania o wymiary aplikacyjne tak szeroko ujmowanego i niejasnego obszaru zadań pedagogicznych, począwszy od definiowania potrzeb, rozpoznawania potencjałów, po tak zwane dobre praktyki, co z kolei powoduje szereg kolejnych uogólnień, stereotypizujących wzmocnień, posiłkowanie się wyjętymi z kontekstu przykładami. Pojawiają się próby mapowania, kategoryzowania, systematyzacji zwłaszcza w obszarze obserwowanych wymykających się fenomenów składających się na tę dynamiczną różnorodność (zob. Gliński i in., 2004). W niektórych rozważaniach społeczność lokalna staje się tylko przestrzenią, w której funkcjonują byty indywidualne - jednostki. Zadaniem wyznaczanym pedagogom społecznym jest wówczas kształtowanie tej przestrzeni tak, aby sprzyjała rozwojowi indywidualnemu, który potrzebuje społecznego kontekstu, a nie, jak to miało miejsce w przeszłości, budowania homogenicznych struktur społecznych, pomijających indywidualne cele.

Znacznie lepszym rozwiązaniem jest, by w miejsce dychotomii: indywidualizm vs. wspólnotowość, przyjąć perspektywę uzupełniających się procesów kształtujących tego samego człowieka w jego osobniczym i zbiorowym (społecznym) wymiarze. Nasz trud wiąże się z antycypowaniem i próbami projektowania warunków lepszej przyszłości oraz uwzględnia niebezpieczeństwo upraszczającej folkloryzacji i sentymentalizacji miejsc (mimo rozumienia ich jako naturalnych procesów chronienia zbiorowego „pamięcio-miejsca” (Theiss, Mendel, 2018).

Tymczasem następuje modyfikacja sposobu widzenia świata. Współczesność domaga się zmiany paradygmatów, uwolnienia miejsca w myśleniu o przestrzeniach nie-miejsc (koncepcja Marca Augéa) dostrzeżeniem perspektyw bycia w wielu miejscach naraz, rzeczywistości poszerzonych/rozszerzonych o wirtualną przestrzeń dzięki cyfrowemu światu (Dejnaka, 2012), a także przekształcania płaskiego obrazu jednorodności i jednowymiarowości fenomenów społecznych w zmienną, wielowymiarową, heterogeniczną strukturę przepływów opisywaną 
przez Manuela Castellsa (Castells, 2010). Potrzebna jest zmiana celów pedagogicznych z dążenia do stanów docelowych, czyli efektów wychowania, w procesy postrzegane jako trasformacje wychowawcze. W hipernowoczesności byt „pedagogizowany" wymyka się pedagogicznej kontroli ku różnorodnym formom twórczej emancypacji, które oczekują od pedagogiki nowego rozumienia bliższego relacjom współbycia i współtworzenia. Nie oczekuje już odgórnych rozwiązań politycznych i pryncypialnych rozwiązań instytucji edukacyjnych.

W naukach społecznych symptomem dostrzeżenia tej zmiany są coraz popularniejsze badania partycypacyjne i podejścia multidyscyplinarne (Theiss, 2008: 77-78; Gierczyk, Dobosz, 2016), coraz mocniej podkreślane różnego rodzaju partnerstwa instytucji praktyki na przykład z grupami obywateli. Tendencje światowe, odzwierciedlające te mechanizmy, prowadzą do upowszechniania idei współprodukcji i współkonstruowania rzeczywistości (ang. co-production, co-construction) oraz współzarządzania (co-governance) jako idei przyświecających zmianie paternalistycznego, opiekuńczego sposobu widzenia tego, co bliskie i „małe”, jednak niepozwalającego na całkowicie oddolne, nieuporządkowane, niekiedy roszczeniowe ruchy separujące bądź selekcjonujące prawo do życia w różnorodności (np. różnego rodzaju lokalne nacjonalizmy).

\section{Poszukiwanie pedagogicznych funkcji rozwoju lokalnego oparte na kategoriach współbycia, współzależności i współodpowiedzialności}

Pedagogom łatwiej być może byłoby zatem skupić się na strukturach relacyjnych kształtujących nie tyle bezpośrednio samą przestrzeń, choć i to jest wskazane, a na pewno bywa konsekwencją trudu zmiany/wzmocnienia owych relacji, ile w sposób pośredni poprzez aktywne towarzyszenie w układaniu wzajemnych sposobów komunikowania, wspólnej realizacji konkretnego działania lub planowania go. Pedagogika społeczna nieustająco bada fenomen społecznych relacji, mających potencjał wychowania. Klasyczne pojęcia sił społecznych, sił ludzkich, ale także więzi, sieci społecznych, kapitału ludzkiego i społecznego, obecne w debatach pedagogicznych, sugerują dostrzeganie wagi tego obszaru dla rozważań o wychowaniu w perspektywie lokalnej (Szczurek-Boruta i in., 2014).

Termin „współbycie” wnosi kolejną ważną cechę do zagadnień wychowawczych z tego obszaru. Ukazuje ontologiczną perspektywę towarzyszącą podejściu do zagadnienia człowieka - istoty społecznej. Być z innymi, a nawet być dla innych, nie zawsze oznacza być wspólnie czy być razem, a być razem nie 
oznacza - tworzyć wspólnotę. Mówił o tym między innymi Martin Luther King, gdy ukazywał, że nie wystarczy być czyimś sąsiadem, przechodzić/przebywać obok kogoś, by go rozumieć, współodczuwać jego problemy i nieść mu pomoc w razie potrzeby (King, 1963). Określenie „współbycie” wprowadza i sugeruje pewną zależność i nierozerwalność różnych losów łączących się w intelektualnym, emocjonalnym i fizycznym wymiarze. Jak wskazuje Bronisława Dymara, w koncepcji pedagogiki współbycia zawarty jest nie tylko aspekt poznawczy, ale i emocjonalny, obejmujący wszystkie przestrzenie interpersonalne (Dymara, 2014: 35). Tylko taki typ przeżywania, myślenia i działania może wskazywać na rzeczywistą integrację społeczną, która wytwarzana jest niejako odśrodkowo, poprzez ludzkie intencje wynikające ze zrozumienia wspólnego połączenia naszych losów, a nie tylko przez najbardziej nawet chlubne inkluzyjne wysiłki zewnętrznych instytucji stosujących różnorodne zabiegi motywacyjne, mobilizujące, oparte o kary i nagrody czy zmuszające do przestrzegania przepisów prawa, które określa formalne ramy tego, co sprawiedliwe.

Namysł pedagogów i wymagająca głębszej refleksji analiza podejścia do idei współbycia zmusza w związku z tym do zweryfikowania naszych narzędzi pracy. Pedagog, stając przed dowolnym zadaniem, potrzebuje sobie odpowiadać na pytanie o działanie wspólnotowe i zintegrowane w myśl idei: „my jako współtwórcy środowiska” i „my jako współodbiorcy” jego wpływów, które tak naprawdę są „naszymi wpływami”. Tego nie można nauczyć, gdyż jest to perspektywa nie tyle modelowania i przekazu wiedzy czy formowania postaw, ile wspólnego doświadczania. Zatem współbycie to współprzeżywanie, współodczuwanie, współtworzenie, ale i ponoszenie współodpowiedzialności za to, co zmieniamy. Nie ma chyba bardziej demokratycznych i bardziej wymagających społecznej (zbiorowej) samoświadomości konsekwencji tak postawionej sprawy. Przedrostek „współ-” niesie potencjał partycypacyjny, emancypacyjny i twórczy, ale jednocześnie prowadzi do zobowiązań oraz zależności (a zatem współzależności i współodpowiedzialności).

W tak rozumianej koncepcji „współżycia” i wspólnego bytowania nie ma bowiem mowy o siedzeniu na ławce obserwatorów. W konsekwencji opozycja i opór ulegają przekształceniu z pozycji „przeciw czemuś, na kierunek „ku czemuś”. Dlatego są to kategorie ważne dla pedagogów społecznych nie tyle w wymiarze tworzenia wspólnoty, która jest ideałem i być może nigdy nie zostanie osiągnięta, nawet nie myślenia wspólnotowego, które wymaga pewnych poszerzonych kompetencji, które obecnie wiele społeczności dopiero stara się rozwijać, ile na tworzeniu fundamentów, na których opierałoby się planowanie budowania (odbudowywania lub przebudowywania) środowisk. 
W pedagogice można by wyróżnić co najmniej trzy obszary, w których kategorie współbycia, współzależności i współodpowiedzialności są istotne (choć z pewnością obszarów tych jest znacznie więcej):

1) aksjologiczny $w$ aspekcie tego, co jest w wychowaniu ważne/priorytetowe/ istotne w kontekście głównego nurtu ocen wartościujących określone działania i rozumienie tego, co to znaczy „bycie wspólne/bycie wspólnie” w wymiarze dialogicznym relacji: Ja-Ty, My-Oni, Ja-My i personalistycznym w odniesieniu do budowania pogłębionych relacji (zob. Dymara, 2014: 36) oraz klasycznej, choć idealistycznej nieco wizji Jacka Delorsa zawartej w koncepcji Edukacji dla wszystkich (w pierwszym z czterech filarów, czyli: uczyć się, aby żyć wspólnie) (Dymara, 2014: 36);

2) formacyjny $w$ aspekcie prorozwojowym, w którym zrozumienie człowie$\mathrm{ka} \mathrm{w}$ relacji $\mathrm{z}$ innymi zawarte jest $\mathrm{w}$ jego realnym doświadczeniu (John Dewey) i przeżywanych, poddawanych refleksji, sprzyjających rozwojowi człowieka jako jednostki bio-psycho-społecznej (Helena Radlińska), która twórczo się rozwija i tranformatywnie uczy (Jack Mezirow), jednocześnie, będąc osobą formowaną, ma potencjał formowania innych;

3) pragmatyki działania (komunikowania, edukacji społecznej) - oparty na zrozumieniu wzajemnym, respektowaniu odmienności celów przy jednoczesnym ustalaniu wspólnego dążenia do rozwoju korzystnego dla wszystkich, jako egzemplifikacji funkcjonowania heterogenicznego świata społecznego kierującego się zasadami pluralizmu, w którym jest miejsce dla każdego.

W tych różnych wymiarach akcentowana jest troska i wrażliwość, szacunek i empatia zbudowane na naturalnych społecznych relacjach opartych na zasadach solidarności społecznej i prawach człowieka, w których, w miejsce relacji władzy i autorytarnych inklinacji, wprowadzamy nową jakość uznania czyjegoś prawa do uczestnictwa. Uczestnictwo bowiem zapewnia aplikacyjne, a nie tylko ideologiczne rozumienie przedrostka „współ-”, zasadzając owe fundamenty na przekonaniu, że budowanie wspólnot lokalnych to proces nieustannej gotowości do uczestniczenia $\mathrm{w}$ określonych działaniach $\mathrm{z}$ uwagi na potrzebę bycia i na wartość bycia potrzebnym. Do tej gotowości potrzebujemy siebie i innych przygotowywać oraz formować warunki sprzyjające jej zaistnieniu. Można w tym miejscu stwierdzić, że w kontekście tradycji polskiej pedagogiki społecznej zdanie to wskazuje na zamknięcie ponadstuletnich rozważań o roli wychowania w środowisku i powrót do początków tworzenia ram dyscypliny.

Rzeczywistość jednak wskazuje, że istnieje nadal realna potrzeba dyskusji o tym, jak pedagodzy społeczni mogą, chcą, potrafią, mają ambicje współ- 
uczestniczyć na poziomie lokalnym w zmianie domagającej się współtworzenia i współpracy, aby kierunek tej zmiany był jak najbardziej przyjazny dla nas wszystkich i być może, w efekcie bardziej psychologicznym niż jakimkolwiek innym, sprawiał nam zwyczajnie radość bycia z innymi ludźmi. Radości tej nie da się wytworzyć najbardziej efektownymi programami społecznymi, najbardziej kolorowymi projektami sąsiedzkimi czy najmądrzejszymi dyskusjami naukowymi. Jest to wyzwanie stojące przed teorią i praktyką pedagogiczną, która nie powinna ani spłycać, ani też komplikować świata opartego o zaufanie, życzliwość czy poczucie bezpieczeństwa w sytuacji bycia $\mathrm{z}$ innymi. Być może niedoścignione marzenie o rzeczpospolitej przyjaciół (określenie za Abramowskim) jest utopijną wizją, która uwodzi swym idealizmem, lecz przekształcanie środowiska w imię ideałów - klasyczne sformułowanie Radlińskiej - już nią nie jest, gdyż oznacza pragmatyczne wezwanie do działania. Zmiana, którą współczesna pedagogika społeczna, korzystająca z kategorii współbycia, współzależności i współodpowiedzialności, dostrzega.

\section{Zakończenie}

Dotychczasowe statyczne (głównie terytorialne) sposoby widzenia społeczności lokalnych miały na celu wspieranie adaptacji, zakorzeniania w istniejących strukturach społecznych, ku dynamicznym i otwartym, różnorodnym przestrzeniom nie-miejsc, w których rozwijają się nowe relacje „lokalne”, oparte na mało stabilnych, jednak coraz bardziej upowszechniających się formach współdzielenia doświadczeń. Zagrożenie pewnymi negatywnymi skutkami nowej plemienności (zob. Maffesoli, 2008) może być przezwyciężone świadomą pracą w nowych środowiskach, które trzeba lepiej zrozumieć i umieć w nich swobodnie funkcjonować. Nowa rzeczywistość wychowawcza o charakterze lokalnym nie tylko oddzieliła się od określonego terytorium, ale i spowodowała, że w wychowaniu zmienia się relacja wychowawca-wychowanek, ku relacjom współwychowawczym. To zaś prowadzi do zmiany także w sferze działania społeczno-wychowawczego ku współdziałaniu, z troski o kogoś ku trosce wzajemnej, z odpowiedzialności pedagogów za wychowanie ku współodpowiedzialności wychowawczej. Istnieje duże prawdopodobieństwo, że o ile ten kierunek będzie utrzymywany, refleksja nad rolą pedagogiki społecznej w kontekście środowisk lokalnych będzie musiała dotyczyć przemodelowania dotychczasowych metod pracy środowiskowej i uwzględnienia partycypacyjnego charakteru relacji wyemancypowanych lub emancypujących się już nie wychowanków, lecz partnerów w wychowaniu. 


\section{Bibliografia}

Banaszak B. (2014), Unia Europejska jako wspólnota wartości, Przegląd Sejmowy, 4(123), s. 9-21.

Bauman Z. (2008), Wspólnota. W poszukiwaniu bezpieczeństwa w niepewnym świecie, przeł. J. Margański, Kraków.

Bąbska B., Rymsza M. (2014), Organizowanie społeczności lokalnej - metodyka pracy środowiskowej, Zeszyty Spraw Publicznych C.A.L., http://www.osl.org.pl/wp-content/uploads/2014/09/ Tryptyk-02_calosc-lekka.pdf, dostęp: 2.08.2019.

Berger P., Luckmann T. (1983), Społeczne tworzenie rzeczywistości, przeł. J. Niżnik, Warszawa.

Castells M. (2010), Społeczeństwo sieci, 2. wyd., Warszawa.

Dejnaka A. (2012), Rzeczywistość rozszerzona i jej zastosowanie w edukacji, E-mentor, 2(44), http:// www.e-mentor.edu.pl/artykul/index/numer/44/id/918, dostęp: 1.08.2019.

Dryżałowska G., Kuleta-Hulboj M., Naumiuk A., Skura M., Steinhagen A. (2019), Inkluzja w perspektywie pedagogiki specjalnej i pedagogiki społecznej. Pytania, konteksty, dyskusje, Warszawa.

Dymara B. (2014), Źródła, cechy i perspektywy pedagogiki współbycia, [w:] U. Szuścik, B. Oelszlaeger-Kosturek (red.), Dziecko w świecie innowacyjnej edukacji, współdziałania $i$ wartości, t. 1, Katowice, s. 29-47.

Gierczyk M., Dobosz D. (2016), Możliwości metodologiczne w badaniach problemów społecznych perspektywa partycypacyjna, Pedagogika Społeczna, 2(60), s. 151-165.

Gliński P., Lewenstein B., Siciński A. (2004), Samoorganizacja społeczeństwa polskiego: III sektor i wspólnoty lokalne w jednoczacej się Europie, Warszawa.

Kazimierczak T. (2012), Koprodukcja, czyli „prawo do miasta” w działaniu - jak poprawić partycypację publiczną przez udział obywateli w świadczeniu usług publicznych, Decydujmy Razem, Wyd. specjalne 2, s. 3-18, http://www.decydujmyrazem.pl/publikacje/decydujmy_razem_/ AiO_2_2012.html, dostęp: 20.09.2019.

King M.L. (1963), On a good neighbour, [w:] B. Barber (red.) (1999), Education for Democracy, Dubuque, Iowa, s. 601-607.

Maffesoli M. (2008), Czas plemion. Schyłek indywidualizmu w społeczeństwach ponowoczesnych, Warszawa.

Mendel M., Naumiuk A., Skrzypczak B. (2018), W trosce o społeczeństwo. Pedagogika społeczna w czasach nacjonalizmu, Pedagogika Społeczna, 4(70), s. 137-159.

Pilch T. (2018), Godność w przekonaniach i praktyce działania pedagogicznego, [w:] W. Danilewicz, J. Niktorowicz, M. Sobecki (red.), Ku życiu wartościowemu. Idee - Koncepcje - Praktyki, t. 2, Kraków, s. 37-53.

Pilch T. (red.) (2006), Encyklopedia pedagogiczna, t. V, Warszawa.

Polityka Spójności UE, Community-Led Local Development, https://ec.europa.eu/regional_policy/sources/docgener/informat/2014/community_en.pdf, dostęp: 2.08.2019.

Radziewicz-Winnicki A. (2013), Społeczność lokalna, zbiorowość terytorialna, a instytucjonalizacja ideologii lokalizmu/regionalizmu, Rocznik Lubuski, vol. 39, cz. 2, s. 13-24.

Segiet K., Słupska K., Tokaj A. (red.) (2017), Animacja w środowisku, O potrzebie kreowania działań lokalnych (teoria i praktyka społeczna), Poznań.

Skrzypczak B. (2016), Wspótczynnik społecznościowy. Edukacyjne (re)konstruowanie instytucji społecznościowych - w perspektywie pedagogiki społecznej, Toruń.

Smolińska-Theiss B. (red.) (1991), Węgrów. Sity społeczne małego miasta, Warszawa. 
Szczurek-Boruta A., Chojnacka-Synaszko B., Suchodolska J. (2014), Człowiek w przestrzeni lokalnej-dobre praktyki wspierania rozwoju, aktywizacji i integracji społecznej. Konteksty teoretyczne, Toruń.

Theiss M. (2008), Participative Action Research. O roli „partycypacyjnych badań w działaniu” w polityce społecznej, Problemy Polityki Społecznej. Studia i Dyskusje, 11, s. 65-85, http://problemypolitykispolecznej.pl/images/czasopisma/11/11_65-85.pdf, dostęp: 4.09.2019.

Theiss W. (2018), Helena Radlińska: powrót do źródeł i tradycji w ponowoczesnym świecie, Pedagogika Społeczna, 4(70), s. 113-123.

Theiss W., Mendel M. (red.) (2019), Pamięć i miejsce. Perspektywa społeczno-edukacyjna, Gdańsk.

Theiss W., Skrzpczak B. (red.) (2006), Edukacja i animacja społeczna w środowisku lokalnym, Warszawa.

Winiarski M. (2006), Współpraca jako wymiar edukacji środowiskowej, [w:] W. Theiss, B. Skrzypczak (red.), Edukacja i animacja społeczna w środowisku lokalnym, Warszawa, s. 35-54.

Winiarski M. (2017), Środowisko wychowawcze i jego kształtowanie w kontekście pedagogiki społecznej, [w:] K. Segiet, K. Słupska, A. Tokaj (red.), Animacja w środowisku, O potrzebie kreowania działań lokalnych (teoria i praktyka społeczna), Poznań, s. 27-46. 